\title{
Laryngeal papillomatosis: correlation between severity of disease and presence of HPV 6 and 11 detected by in situ DNA hybridisation
}

\author{
R E QUINEY,* M WELLS, $\dagger$ F A LEWIS, $\dagger$ R M TERRY $\ddagger$ L MICHAELS,$\S$ C B CROFT* \\ From the *Department of Otolaryngology, Royal National Throat, Nose and Ear Hospital, London, the \\ $\dagger$ Department of Pathology, University of Leeds, the $\ddagger$ Department of Otolaryngology, Leeds General Infirmary, \\ and the §Department of Histopathology, University College and Middlesex School of Medicine, London
}

SUMMARY A technique using a biotin-streptavidin polyalkaline phosphatase complex was applied to routinely fixed and processed biopsy specimens of laryngeal papillomata from 45 patients taken over the past 20 years to detect human papilloma virus (HPV) types 6 and 11 . Two thirds of both adult and juvenile onset cases were positive for HPV 6 or HPV 11 or both. Five specimens of normal vocal cord epithelium were negative for HPV 6 and 11. The detailed clinical history, endoscopic findings, success of treatment and eventual prognosis were compared with the HPV state of biopsy material for each patient. Patients with multiple confluent lesions when first seen, whose histology showed florid koilocytosis and who had strongly positive reactivity for HPV 6 or 11 present in the surface epithelial cell nuclei, had a poor prognosis requiring multiple endoscopies to control their disease.

The viral aetiology of laryngeal papillomatosis was first suggested in 1923 by Ullman, who reported the experimental transmission of warts to the vagina of a dog and to his own arm using an extract of human laryngeal papilloma.' The demonstration of viral particles within laryngeal papilloma tissue using either electron microscopy ${ }^{2}$ or immunohistochemical techniques, ${ }^{34}$ however, has met with only very limited success. Svoboda et $a l^{5}$ and Stephens et al ${ }^{6}$ failed to detect virus particles in 33 biopsy specimens of laryngeal papillomata by electron microscopy examination. This difficulty in detecting virus particles led to the putative viral aetiology of laryngeal papilloma being questioned because, by contrast, virus particles are frequently seen and easily shown in skin warts. ${ }^{7}$ Recently Southern blotting techniques ${ }^{8}$ using radioactive probes have been used to confirm viral DNA in papillomata but such techniques do not permit the accurate localisation of the virus within the tissue. Specific subtypes of human papilloma virus can now be localised in tissue fixed in formaldehyde and embedded in paraffin wax using both radioactive probes, ${ }^{910}$ and more recently using biotinylated probes. ${ }^{11-13}$

Despite the low incidence both juvenile and adult laryngeal papillomatosis have a high prevalence because multiple endoscopies are often required to

Accepted for publication 2 March 1989 control the disease. There is a wide spectrum of severity in this condition; some adults with solitary papillomata are cured after a single endoscopy while at the other extreme some children with multiple papillomata arising from multiple laryngeal sites require a tracheostomy and tens if not hundreds of endoscopies to control spread. Two patients in our series required laryngectomies to control their disease. ${ }^{14}$ The clinical spectrum of the disease seen at the Royal National Throat, Nose and Ear Hospital in 113 patients over the past 20 years has been reported separately. ${ }^{15}$

The present study was undertaken with two main aims: firstly, to confirm the high incidence of human papilloma virus (HPV) 6 and 11 using in situ DNA hybridisation; and secondly, to compare these molecular biological findings with the clinical pattern seen in patients followed up for many years with several biopsies.

\section{Patients and methods}

A total of 113 patients have been treated at the Royal National Throat, Nose and Ear Hospital with laryngeal papillomatosis over the past 20 years. Histopathological blocks of the first $\mathbf{4 5}$ patients were retrieved and the histology reviewed. Information was collected from the case notes on the patient's age at presentation, sex, smoking habits, occupation, marital status, 
date of onset of symptoms, initial sites of disease recorded at the first endoscopy, the total number of microlaryngoscopies, the complications of treatment and the eventual outcome. A total of 118 tissue blocks were submitted for histological review and in situ DNA hybridisation using the following method.

\section{PRETREATMENT}

All tissue had been fixed in formaldehyde and embedded in paraffin wax. Sections 3-5 $\mu \mathrm{m}$ thick were placed on 3-amino propyl triethoxysilane coated single well slides and hotplated to ensure maximum tissue adhesion. Sections were dewaxed in xylene at $37^{\circ} \mathrm{C}$ for 30 minutes, xylene at room temperature for $10 \mathrm{~min}$ utes, and absolute alcohol twice for 10 minutes. The sections were hydrated through a series of graded alcohols to distilled water and immersed in phosphate buffered saline for five minutes. The slides were transferred to $0.2 \mathrm{M} \mathrm{HCl}$ for 10 minutes, incubated in $0.1 \%$ Triton X-100 for three minutes to permeabilise membranes, and digested with proteinase $\mathbf{K}$ for 15 minutes at $37^{\circ} \mathrm{C}$ to access the cellular DNA. After washing in several changes of phosphate buffered saline the slides were placed in $20 \%$ acetic acid in water at $4^{\circ} \mathrm{C}$ for 15 seconds to destroy endogenous tissue alkaline phosphatase and post-fixed in $4 \%$ paraformaldehyde before dehydration through graded alcohols to $100 \%$ ethanol.

\section{HYBRIDISATION}

The DNA probes used were HPV 6 and HPV 11 linked to the plasmid pBR322 and were a gift from Professor Harald zur Hausen (Heidelburg, West Germany). The probes were biotinylated with biotin-11-dUTP using a nick translation kit (Gibco-BRL, High Wycombe, Buckinghamshire). The biotinylated probes were prepared at a concentration of $200 \mathrm{ng} / \mathrm{ml}$ in a hybridisation buffer containing $2 \times \mathrm{SSC}, 5 \%$ dextran sulphate, $0.2 \%$ dried milk powder, $50 \%$ formamide $(1 \times \mathrm{SSC}=0.15 \mathrm{M}$ sodium chloride, $0.015 \mathrm{M}$ sodium citrate).

Hybridisation mixture ( $75 \mu \mathrm{l})$ (12 ng DNA probe) was added to each prepared section, the well was covered with a piece of Gel Bond (ICN Biochemicals, Paisley, Scotland), hydrophobic side down, and sealed with nail varnish. Cellular and probe DNA were made single stranded by heating the slides at $90^{\circ} \mathrm{C}$ for 10 minutes, and hybridisation was carried out overnight at $42^{\circ} \mathrm{C}$.

\section{DETECTION OF HYBRIDISATION SIGNAL}

After removing the Gel Bond cover slip the slides were immersed in $3 \%$ bovine serum albumin for five minutes to block all non-specific streptavidin-binding sites in the tissue. Streptavidin was then added to each slide and incubated for 20 minutes. This protein
Table 1 Results of DNA in situ hybridisation for adult laryngeal papillomata

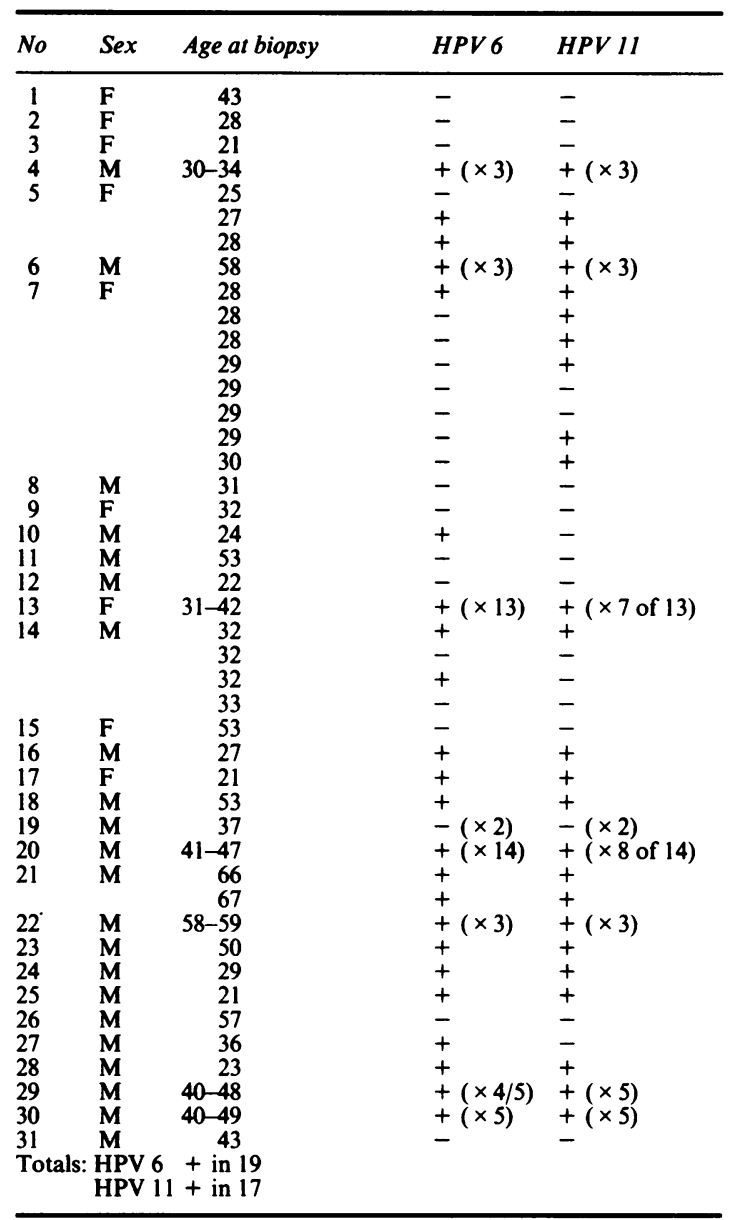

Table 2 Results of DNA in situ hybridisation for juvenile laryngeal papillomata

\begin{tabular}{|c|c|c|c|c|}
\hline No & Sex & Age at biopsy & HPV 6 & $H P V 11$ \\
\hline 1 & $\mathbf{M}$ & 6 months & - & - \\
\hline 2 & $\mathbf{F}$ & 3 & $=$ & $\overline{-}$ \\
\hline \multirow[t]{2}{*}{3} & \multirow[t]{2}{*}{$\mathbf{F}$} & 6 & - & + \\
\hline & & $\begin{array}{r}10 \\
6\end{array}$ & \pm & \pm \\
\hline 5 & $\mathbf{M}$ & $8-18$ & $+(\times 5 / 11)$ & $+(\times 9 / 11)$ \\
\hline 6 & $\mathbf{F}$ & $9-15$ & $-(\times 6)$ & $+(\times 3 / 6)$ \\
\hline 7 & $\mathbf{F}$ & 7 & + & + \\
\hline 8 & $\mathbf{F}$ & 3 months & + & + \\
\hline 9 & $\mathbf{F}$ & 5 & $-(\times 2)$ & $-(\times 2)$ \\
\hline 10 & $\mathbf{F}$ & 8 months & + & - \\
\hline 11 & $\mathbf{M}$ & 5 & $+(\times 2)$ & $+(\times 2)$ \\
\hline 12 & $\mathbf{M}$ & 5 & $-(\times 3)$ & $-(\times 3)$ \\
\hline 13 & & $13-14$ & $+(\times 2)$ & $+(\times 2)$ \\
\hline 14 & M & 6 months & - & + \\
\hline Totals: & $\begin{array}{l}\text { HPV } 6 \\
\text { HPV } 11\end{array}$ & $\begin{array}{l}+ \text { in } 7 \\
+ \text { in } 8\end{array}$ & & \\
\hline
\end{tabular}




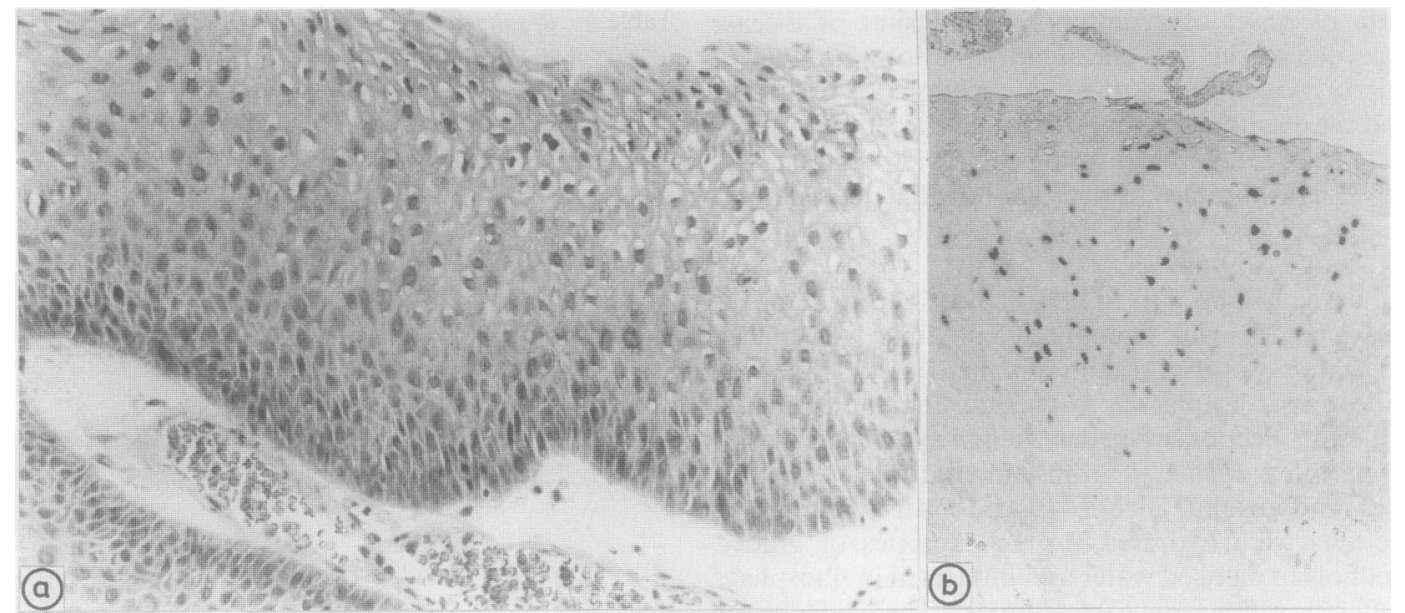

Fig 1 Photomicrograph of human laryngeal papilloma. (a) Section showing florid koilocytosis. (Haematoxylin and eosin.) (b) HPV 6 probe (dark stain confined to nuclei of superficial cells).

tetramer binds strongly with biotin. The slides were washed free of excess streptavidin and incubated with biotinylated alkaline phosphatase to react with the remaining biotin binding sites on the bound streptavidin. The alkaline phosphatase was detected by reaction with a substrate containing nitroblue tetrazolium and 5-bromo-4-chloro-3-indolyl phosphate to produce a purple blue precipitate at the site of hybridisation. The slides were then counterstained with methyl green. The full technique has been reported in detail elsewhere."

Six sections were taken from each tissue block. These were for (i) haemotoxylin and eosin stain to check histological detail: (ii) in situ hybridisation using HPV 6 and 11 probes: (iii) a positive control of total human DNA and; (iv) two negative controls of pBR 322 without probe and hybridisation buffer alone. All slides were reviewed by three of the six authors (RQ,MW, FL). Doubtful cases or the few cases in which there was non-agreement between observers were regarded as negative.

\section{Results}

The results of in situ DNA hybridisation for juvenile and adult laryngeal papillomata are shown in tables 1

Table 3 Correlation between sex of patient and presence of HPV 6 and 11 in laryngeal papilloma in 45 patients

\begin{tabular}{|c|c|c|}
\hline & Male & Female \\
\hline $\begin{array}{l}\text { HPV } 6 \text { and/or } 11 \text { present } \\
\text { Negative for HPV } 6 \text { and } 11\end{array}$ & $\begin{array}{r}19 \\
7\end{array}$ & $\begin{array}{r}9 \\
10\end{array}$ \\
\hline $\begin{array}{l}\chi^{2} \text { test (with Yates' correction) }=2.087 \\
\mathrm{df}=1 \\
\mathrm{p}<0.2 \text { (not significant) }\end{array}$ & & 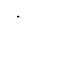 \\
\hline
\end{tabular}

and 2. The hybridisation signal was always confined to the nuclei and was only regarded as positive if it was seen in numerous cells in the superficial squamous epithelium. There was good correlation between a positive hybridisation signal and the presence of koilocytosis seen on histological review (fig 1).

In both juvenile and adult onset cases about two thirds of all patients had more than one slide positive for either HPV 6 or 11. Most positive blocks were positive for both HPV 6 and 11. Five specimens of normal vocal cord from patients with no laryngeal disease were negative.

There were no significant correlations between the finding of HPV 6 or 11 and sex (table 3) or age (table 4) of the patient. In the adults smoking habits did not relate to the finding of HPV 6 or 11 in papilloma tissue. The site of papillomata in the larynx at first endoscopy has been reported in a previous paper. ${ }^{15}$ No correlation between original site of disease and the finding of HPV 6 or 11 could be made, but in those patients with gross disease when first seen-that is, multiple sites, confluent lesions - there was an increased incidence of positive findings of HPV 6 or 11 compared with single lesions (table 5), and this is significant ( $\chi^{2}$ test with Yates' correction $=3.97 p<0.01$ ).

Many patients have had multiple endoscopies, using

Table 4 Correlation between age of patient at presentation and presence of HPV 6 and 11 in laryngeal papilloma in 45 patients

\begin{tabular}{lcl}
\hline & $\begin{array}{l}\text { Juvenile onset } \\
\text { (age <16 yrs) }\end{array}$ & $\begin{array}{l}\text { Adult onset } \\
\text { (age > 16 yrs) }\end{array}$ \\
\hline HPV 6 and/or 11 present & 8 & 20 \\
Negative for HPV 6 and 11 & 6 & 11 \\
$\chi^{2}$ test (with Yates' correction) & 1.96 not significant \\
\hline
\end{tabular}


Table 5 Severity of disease when first seen related to presence of HPV 6 and 11 in laryngeal papilloma in 45 patients

\begin{tabular}{|c|c|c|}
\hline & \multicolumn{2}{|c|}{$\begin{array}{l}\text { Type of disease at initial } \\
\text { endoscopy }\end{array}$} \\
\hline & Single isolated & Multiple confluent \\
\hline $\begin{array}{l}\text { Positive for HPV } 6 \text { and/or } 11 \\
\text { Negative for HPV } 6 \text { and } 11\end{array}$ & $\begin{array}{l}2 \\
6\end{array}$ & $\begin{array}{l}26 \\
11\end{array}$ \\
\hline $\begin{array}{l}\left.\chi^{2} \text { (with Yates' correction }\right)=3.97 \\
\mathrm{p}<0.05\end{array}$ & & \\
\hline
\end{tabular}

the carbon dioxide laser to vaporise papillomata. Although at initial endoscopy tissue was always sent for histological confirmation, in those patients who had multiple endoscopies, biopsy specimens were not always obtained. Nevertheless, in several cases multiple tissue blocks containing tissue taken from the same patient over several years were available for analysis. Many such cases, such as case 20 (table 1), showed a high concordance of positive findings for HPV 6 and 11 between blocks.

Fig 2 shows the relation between the numbers of microlaryngoscopies and the age of the patient for 113 patients seen at the Royal National Throat, Nose and Ear Hospital, with labels for the $\mathbf{4 5}$ patients whose blocks have been examined. This shows that the survey sample of $\mathbf{4 5}$ is a representative sample of the total. Although there is no difference in overall incidence of HPV 6 and 11 between the juvenile and adult onset cases, the scatter graph shows an inverse association between the patient's age at presentation and the number of microlargyngoscopies required.

Follow up of patients varied between one month and 60 years in the original group of 113 patients, with

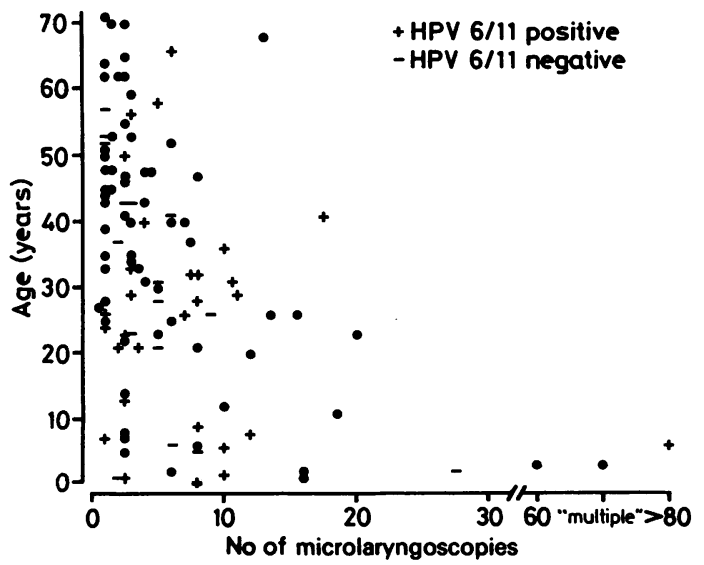

Fig 2 Scatter graph showing relation between age of patient and onset at disease and total number of microlaryngoscopies in 113 patients. Patients whose biopsy material underwent DNA hybridisation marked ( + ) and (-).
Table 6 Correlation between eventual control of disease and presence of HPV 6 or 11 in laryngeal papilloma tissue in 45 patients

\begin{tabular}{|c|c|c|}
\hline & $\begin{array}{l}\text { Well } \\
\text { controlled } \\
\text { disease }\end{array}$ & $\begin{array}{l}\text { Uncontrolled disease } \\
\text { (<8 endoscopies or } \\
\text { further endoscopies } \\
\text { needed) }\end{array}$ \\
\hline $\begin{array}{l}\text { Positive for HPV } 6 \text { or } 11 \\
\text { Negative for HPV } 6 \text { and } 11\end{array}$ & $\begin{array}{l}12 \\
15\end{array}$ & $\begin{array}{r}16 \\
2\end{array}$ \\
\hline \multicolumn{3}{|c|}{$\begin{array}{l}\chi^{2} \text { test }(\text { with Yates' correction) }=7.28 \\
\mathrm{p}<0.01\end{array}$} \\
\hline
\end{tabular}

an average of nine years, but in the sample group of 45 patients follow up was for a minimum of eight years (mean 12.5 years). Eventual disease control by whatever treatment method chosen (carbon dioxide laser, suction diathermy, painting lesions with podophyllin, interferon treatment, BCG injections) has been well documented and well reviewed by Robbins and Woodson. ${ }^{16}$ Most of our patients underwent both suction diathermy as described by Pracy ${ }^{17}$, and more recently, the carbon dioxide laser which is now the method of choice. ${ }^{18} 19$

There was a highly significant correlation between eventual outcome of disease and presence of HPV 6 and 11 in biopsy tissue in our patients (table 6) with a $p$ value of less than 0.001 .

\section{Discussion}

In contrast to our predominantly adult group (87 of 113), Strong et al reported on a similar sized group of 110 patients, most of whom developed disease while juvenile. ${ }^{18}$ The reason the two age groups have been separated is threefold. Firstly, the sex ratio in adults and children with the disease was different. In the adult group most were male ${ }^{19}$ while in the juvenile onset group most were female. ${ }^{20}$ Analysis of the male : female ratio with respect to age in our own group of 113 patients showed a highly significant sex difference between juvenile and adult onset $\operatorname{cases}\left(\chi^{2}=\right.$ $9.53 \mathrm{p}<0.01) .^{15}$

Secondly, in the juvenile onset cases the initial site of papilloma was more widespread, often affecting the subglottis and supraglottis as well as the glottis, while in the adult group lesions initially appear more frequently on the vocal cords alone. Furthermore, treatment in juvenile onset cases is generally more difficult and more prolonged than in adult onset cases and this is shown in fig 2 . Children whose airways are of overall smaller diameter than adults need microlaryngoscopies more frequently and end up requiring tracheostomies more often than adults. After tracheostomy spread of papillomata down the trachea to the main bronchi is more florid and more 
difficult to treat in children. The third difference between adult and juvenile onset disease is the imputed aetiology. How adults are infected by a virus disease is not known. In children the presumed mechanism is inhalation of secretions at the time of birth and spread of virus to the newborn from genital condylomata. Both laryngeal papilloma and condylomata have the same HPV 6 and 11 subtypes implicated in their aetiology. ${ }^{1213}$

Both juvenile and adult groups have a positive incidence of about $66 \%$. The fact that cell nuclei in the basal cells of papillomata are negative while the surface cell nuclei are strongly positive is probably because there are fewer copies of viral DNA in the basal cell nuclei. The positivity rate found in the present series was clearly different to that reported in our previous paper ${ }^{21}$ in which all of the juvenile papillomata but only seven out of 25 cases of adult papillomata were positive for HPV type 6 or type 11, or both. As discussed in detail in our earlier paper these discrepancies may well reflect different fixation procedures between hospital laboratories. This is a limitation of any retrospective study in which cases are accrued over a long period. Although geographic variations may also be a factor in these differences, on balance this seems to be a less likely explanation.

The demonstration of a significantly higher incidence of HPV 6 and 11 in multiple confluent papilloma compared with single isolated papillomata at the initial endoscopy, and the further finding that poor control of disease shows a close association with the presence of HPV 6 or 11 , or both, is an important new finding. The endoscopic findings at initial endoscopy have already been correlated with eventual prognosis. ${ }^{150}$ The detection of HPV 6 and 11 in biopsy specimens at initial endoscopy might also be a useful prognostic factor, because those patients whose biopsy tissue has a large number of nuclei positive for HPV 6 and 11, especially on more than one occasion, are more likely to have a worse eventual outcome. These differences may reflect the varying immune responses of patients to the presence of virus; data concerning host immune responses to papilloma virus in any site are presently not available.

The persistence of HPV 6 or 11 in papillomatous tissue could be used to indicate the efficacy of treatment. This has recently been used to monitor interferon treatment ${ }^{22}$ and the persistence of HPV 6 or 11 used as an explanation for the poor response following this treatment in many patients.

This work was supported by a grant to Dr M Wells from the Yorkshire Cancer Research Campaign.

We thank Deborah Walker for valuable technical assistance.
References

1 Ullman EV. On the aetiology of laryngeal papilloma. Acta Otolaryngol 1928;5:317-38.

2 Boyle WF, Riggs JL, Oshiro LS, Lennette EH. Electron microscopic identification of PAPOVA virus in laryngeal papillomata. Laryngoscope 1978;83:1102-8.

3 Lock EE, Jenson AB, Smith HG, Healey GB, Pass F, Vawter GF. Immunoperoxidase localisation of human papillomavirus in laryngeal papillomas. Intervirology 1980;14:148-54.

4 Braun L, Kashima H, Eggleston J, Shah K. Demonstration of papillomavirus antigen in paraffin sections of laryngeal papillomas. Laryngoscope 1982;92:640-3.

5 Svoboda DJ, Kirchner FR, Provd GO. Electron microscopic study of human laryngeal papillomatosis. Cancer Res 1963;23:1084-9.

6 Stephens CB, Arnold GE, Butchko GM, Hardy CL. Autogenous vaccine treatment of juvenile laryngeal papillomatosis. Laryngoscope 1979;89:1689-96.

7 Melnick JL. Papovavirus group. Science 1962;135:1128-30.

8 Gissman L, Wolnick L, Ikenburg H, et al. Human papillomavirus types 6 and 11 DNA sequences in genital and laryngeal papillomas and in some cervical cancers. Proc Natl Acad Sci USA 1983;80:560-3.

9 Gupta J, Gendelman HE, Naghasfor Z, et al. Specific identification of human papillomavirus type in cervical smears and paraffin sectors by in-situ hybridisation with radioactive probes. Int J Gynecol Pathol 1985;4:211-8.

10 Stoler MH, Broker TR. In-situ-hybridisation detection of human papillomavirus DNAs and messenger RNAs in genital condylomas and a cervical carcinoma. Hum Pathol 1986;17:1250-8.

11 Lewis FA, Griffiths S, Dunicliff R, Wells M, Dudding N, Bird CC. Sensitive in situ hybridisation technique using biotin-streptavidin-polyalkaline phosphatase. J Clin Pathol 1987;40:163-6.

12 Wells M, Griffiths S, Lewis FA, Bird CC. Demonstration of human papillomavirus types in paraffin processed tissue from human ano-genital lesions by in-situ DNA hybridisation. J Pathol 1987;152:77-82.

13 Terry RM, Lewis FA, Griffiths S, Wells M, Bird CC. Demonstration of human papillomavirus types 6 and 11 in juvenile laryngeal papillomatosis by in-situ hybridisation. $J$ Pathol 1987;153:245-8.

14 Robbins KT, Howard D. Multiple laryngeal papillomatosis requiring laryngectomy. Arch Otolaryngol 1983;109:765-9.

15 Quiney RE, Hall D, Croft CB. Laryngeal papillomatosis revisited; analysis of 113 patients. Clin Otol 1989;14:217-25.

16 Robbins KT, Woodson GE. Current concepts in the management of laryngeal papillomatosis. Head Neck Surg 1984;6:861-6.

17 Pracy R. Children's laryngology. J Laryngol Otol 1976;84:37-40.

18 Strong MS, Vaughan CW, Healey GB, Cooperbrand SR, Clemente MACP. Recurrent respiratory papillomatosis management with the $\mathrm{CO}_{2}$ laser. Ann Otol Rhinol Laryngol 1976;85:508-16.

19 Robb PJ. The $\mathrm{CO}_{2}$ laser and management of recurrent laryngeal papilloma: the Guy's experience. J Laryngol Otol 1987;101: 369-75.

20 Lindberg H, Oster S, Oxlund I, Elbrand O. Laryngeal papillomatosis; classification and course. Clin Otol 1986;11:423-9.

21 Terry RM, Lewis FA, Robertson S, Blythe D, Wells M. Juvenile and adult laryngeal papillomata: classification by in-situ hybridisation for human papillomavirus. Clin Otol 1989; 14:135-40.

22 Steinberg BM, Gallagher T, Stoler M, Abramson AL. Persistence and expression of human papillomavirus during interferon therapy. Arch Otolaryngol 1988;114:27-32.

Requests for reprints to: Dr R E Quiney, Royal National Throat, Nose and Ear Hospital, Gray's Inn Road, London WCIX 8DA, England. 